\title{
Dissolved iron distribution in the tropical and sub tropical South Eastern Pacific
}

\author{
S. Blain ${ }^{1, *}$, S. Bonnet ${ }^{2}$, and C. Guieu ${ }^{2}$ \\ ${ }^{1}$ Laboratoire d'Océanographie et de Biogéochimie, Campus de Luminy, case 901, 13288 Marseille cedex, France \\ ${ }^{2}$ Laboratoire d'océanographie de Villefranche sur mer, Quai de la darse, Villefranche sur mer, France \\ * present address: UPMC Univ. Paris 06, UMR 7621, Laboratoire d'Océanographie Biologique, 66650 Banyuls/mer, France
}

Received: 13 July 2007 - Published in Biogeosciences Discuss.: 24 August 2007

Revised: 20 December 2007 - Accepted: 18 January 2008 - Published: 27 February 2008

\begin{abstract}
Dissolved iron (DFe) distributions $(<0.2 \mu \mathrm{m})$ were determined in the upper water column $(0-400 \mathrm{~m})$ of the south eastern tropical and subtropical Pacific, in OctoberNovember 2004. Data were collected along a transect extending from the Marquesas Islands to the Chilean coast with most of the stations located in the south Pacific gyre. The concentrations of DFe presented large variability with highest values observed at both extremities of the transect. In the Chilean upwelling, DFe concentrations ranged between $1.2-3.9 \mathrm{nM}$. These high values result from inputs from the continental margin and are likely maintained by anoxic conditions in the water corresponding to the Oxygen Minimum Zone (OMZ). In subsurface waters near the Marquesas, that were also associated with the extension of the OMZ, DFe concentrations varied between $0.15-0.41 \mathrm{nM}$. Vertical transport of this water by mesoscale activity eastward of the archipelago may explain the dissymmetric east-west distribution of chlorophyll- $a$ evidenced by satellite images. Using the new tracer $\mathrm{Fe}{ }^{*}=\mathrm{DFe}-r_{\mathrm{Fe}: \mathrm{P}}\left(\mathrm{PO}_{4}^{3-}\right)$ we show that $\mathrm{DFe}$ was in deficit compared to $\mathrm{PO}_{4}^{3-}$ resulting from the remineralisation of organic matter. This suggests that the Marquesas islands and the surrounding plateau are not a significant source of DFe. In the gyre, DFe concentrations in the upper $350 \mathrm{~m}$ water column were around $0.1 \mathrm{nM}$ and the ferricline was located well below the nitracline. These low concentrations reflect the low input of DFe from the atmosphere, from the ventilation of the upper thermocline with water containing low DFe, and from the low biological activity within this ultra oligotrophic gyre.
\end{abstract}

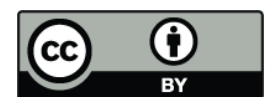

Correspondence to: S. Blain (stephane.blain@obs-banyuls.fr)

\section{Introduction}

Iron is now recognised as an important element involved in numerous biochemical processes in the ocean. In High Nutrient Low Chorophyll (HNLC) regions, iron is the proximate control of organic matter production as was clearly demonstrated by artificial iron fertilisation experiments (Boyd et al., 2007). A natural iron fertilisation experiment carried out in the largest HNLC region, the Southern Ocean (Blain et al., 2007), has revealed that the carbon export is extremely sensitive to iron inputs, much more than previously thought from artificial iron fertilisation experiments. Evidence for iron limitation of biological productivity was also found in other environments including coastal upwelling (Hutchins and Bruland, 1998), mesotrophic (Blain et al., 2004) and oligotrophic (Sedwick et al., 2005) systems. Oligotrophic systems generally provide an ideal ecological niche for the development of nitrogen-fixing organisms (e.g. (Capone et al., 2005; Karl, 2002). Due to the high cellular iron quota in diazotrophs compared to non diazotrophic phytoplankton (Kustka et al., 2003), iron availability also exerts a control on nitrogen fixation and new primary productivity (Mills et al., 2004; Moore and Doney, 2007).

The distribution of dissolved iron (DFe) in seawater depends on the nature and the magnitude of the sources and sinks and on the transport mechanisms. The two major external sources of iron to the ocean are dust deposition from the atmosphere (Jickells et al., 2005) and inputs from the sediments (Elrod et al., 2004; Johnson et al., 1999). The fingerprint of dust deposition was clearly detectable in the DFe surface concentrations in different regions (Bonnet and Guieu, 2006; Boyle et al., 2005; Guieu et al., 2002; Sedwick et al., 2005). However, the magnitude of the atmospheric source of DFe is still very difficult to quantify because it requires determining both the flux of deposition and the solubility of dust. Qualitative evidence of the input from the sediment has mainly been reported for continental shelf or

Published by Copernicus Publications on behalf of the European Geosciences Union. 
along the continental margin (Laës et al., 2007; Martin et al., 1989). But again the magnitude of the source is not well constrained due to the few quantitative studies on 2007. Elrod et al. (2004) pointed out large discrepancies between fluxes measured in benthic chambers and those inferred from DFe profiles in pore waters. Besides these two major sources, hydrothermalism (Boyle et al., 2005), pack ice or iceberg melting (Sedwick and Di Tullio, 1997) can locally also impact the vertical DFe distribution. The major sinks in the ocean are the net biological uptake and scavenging by sinking particles. The combination of mixing and sinking tends to rapidly decrease $\mathrm{DFe}$ concentrations at locations away from the source. This horizontal trend was fitted by an exponential law with e-fold (Bucciarelli et al., 2001; Johnson et al., 1997). However, in deep waters where scavenging is reduced due to the low abundance of particles, DFe can be transported over long distances (Laës et al., 2003).

In regions where dust deposition is low, the deep ocean is the main reservoir of DFe for surface waters. In this context, the determination of DFe fluxes resulting from diapycnal and deep winter mixing is crucial to quantify the input of new iron to the surface layer and to compare it with the iron demand of phytoplankton (Blain et al., 2007). In some areas, vertical upwelling may also be a major pathway for transporting iron from the deep sea to the surface layer (Johnson et al., 1999). Although no direct observation is available, vertical movement induced by mesoscale or sub-mesoscale activities may also promote upward iron transport.

During the past decade, models that include different degrees of complexity for the iron cycle and for the coupling with other biogeochemical cycles were developed (Aumont et al., 2003; Johnson et al., 1997; Moore et al., 2004; Parekh et al., 2005; Weber et al., 2007). They are used to test the sensitivity of the iron cycle to processes like scavenging, dissolution, complexation with organic ligands, and allow drawing some conclusions on the factors that control the iron distribution in seawater and the subsequent effect on biological processes (i.e. primary production, nitrogen fixation). The validation of these models is largely dependent on the spatial and temporal coverage of DFe distributions in the global ocean. The most recent compilation of iron data in the world ocean (Parekh et al., 2005) shows that although the number of data available is rapidly growing, some large regions are still poorly or not at all sampled. This is the case for the south eastern subtropical Pacific which is also largely undersampled for most of the other biogeochemical and biological parameters. The BIOSOPE cruise has filled this gap with a long transect extending from the Marquesas archipelago to the Chilean coast. We report here the DFe concentrations in the upper $400 \mathrm{~m}$ of the water column. The vertical and horizontal distributions are discussed in relation with the possible sources and sinks of iron.

\section{Material and methods}

\subsection{Fe determination}

The BIOSOPE cruise took place in October-November 2004. The upper water column $(0-400 \mathrm{~m})$ was sampled at 19 stations (Table 1) along the $8000 \mathrm{~km}$ transect (Fig. 1a). From the surface to $50 \mathrm{~m}$, seawater was collected using a clean Teflon pump connected to a PVC tube attached to a Kevlar cable. In-line filtration was performed through a $0.2 \mu \mathrm{m}$ cartridge (Sartorius Sartrobran-P-capsule $0.45 \mathrm{~mm}$ prefilter and $0.2 \mathrm{~mm}$ final filter) in a clean laboratory container.

Below $50 \mathrm{~m}$, samples were collected with acid-cleaned 121 Teflon-coated GO-Flo bottles mounted on a Kevlar cable (length $450 \mathrm{~m}$ ) and tripped by Teflon messengers. The bottles were then brought to a clean van for sub sampling. The GO-Flo bottles were gently pressurised with high purity nitrogen allowing on-line filtration through Sartroban cartridges $(0.2 \mu \mathrm{m}$ with a $0.4 \mu \mathrm{m}$ prefilter, Sartorius). All the filtered samples for DFe analysis were collected in duplicate, in acid-cleaned $60 \mathrm{ml}$ low density polyethylene bottles and immediately acidified with ultrapure $\mathrm{HCl}(60 \mu 1,9.5 \mathrm{mM}$ final concentration, Merck, ultrapur $\left.{ }^{(}\right)$under a class 100 laminar flow hood. The samples were left for at least $24 \mathrm{~h}$ before analysis.

The concentrations of DFe were measured on board by Flow Injection Analysis with chemiluminescence detection (adapted from Obata et al., 1993). The $\mathrm{pH}$ of the acidified samples was adjusted to 5 using Ultrapur ammonia and a 3times purified ammonium acetate buffer before loading for $120 \mathrm{~s}$ on the 8 hydroxyquinoline ( $8 \mathrm{HQ}$ ) preconcentration column ( $1 \mathrm{~cm}$ long). The mean blank, calculated from daily determinations, equalled $69 \pm 18 \mathrm{pM}(n=19)$ and the detection limit was $54 \mathrm{pM}$. The accuracy was assessed by re-analysing one vertical profile (6 samples) of the BIOSOPE cruise during the KEOPS cruise (Blain et al., 2008) in parallel with the new reference material from the SAFE cruise (North Pacific gyre, same period as BIOSOPE). Both profiles analyzed during BIOSOPE and KEOPS were not statistically different (t-test, $p<0.01$ ), indicating a good accuracy of the method.

\subsection{Ancillary measurements}

Temperature, salinity, and dioxygen $\left(\mathrm{O}_{2}\right)$ were determined from CTD casts performed at each station. Samples for nutrient analyses were collected both from GO-Flo and Niskin casts. The comparison between both data sets was used to detect possible malfunctioning of the GO-Flo bottles (e.g. leaks). Dioxygen was measured by the Winkler method with potentiometric endpoint detection. Nitrate and phosphate concentrations were measured using a Technicon Autoanalyser II (Tréguer and Le Corre, 1975). For low nitrate concentrations, the method described in (Raimbault et al., 2007) was used. All the nutrient data presented in this paper are from GO-Flo bottles allowing the direct comparison with DFe. 
Table 1. Data.

\begin{tabular}{|c|c|c|c|c|c|c|c|}
\hline Station & $\mathrm{mon} / \mathrm{day} / \mathrm{yr}$ & Lon $\left({ }^{\circ} \mathrm{E}\right)$ & Lat $\left({ }^{\circ} \mathrm{S}\right)$ & Depth (m) & $\mathrm{DFe}(\mathrm{nM})$ & $\mathrm{NO}_{\mathrm{X}}(\mu \mathrm{M})$ & $\mathrm{PO}_{4}(\mu \mathrm{M})$ \\
\hline \multirow{9}{*}{ MAR3 } & \multirow{9}{*}{$10 / 29 / 2004$} & \multirow{9}{*}{-141.2777} & \multirow{9}{*}{-8.3213} & 10 & 0.19 & & \\
\hline & & & & 30 & 0.17 & & \\
\hline & & & & 50 & 0.18 & 2.26 & 0.36 \\
\hline & & & & 80 & 0.14 & 3.03 & 0.41 \\
\hline & & & & 110 & 0.19 & 3.81 & 0.46 \\
\hline & & & & 140 & 0.15 & 7.14 & 0.61 \\
\hline & & & & 190 & 0.12 & 9.51 & 0.86 \\
\hline & & & & 240 & 0.20 & 13.1 & 1.45 \\
\hline & & & & 350 & 0.42 & 18.4 & 2.38 \\
\hline \multirow{5}{*}{ NUK1 } & \multirow{5}{*}{$10 / 30 / 2004$} & \multirow{5}{*}{-140.1076} & \multirow{5}{*}{-8.9768} & 30 & 0.16 & 0.04 & 0.24 \\
\hline & & & & 50 & 0.16 & 0.01 & 0.24 \\
\hline & & & & 80 & 0.19 & 0.82 & 0.29 \\
\hline & & & & 110 & 0.13 & 5.34 & 0.57 \\
\hline & & & & 130 & 0.17 & 5.57 & 0.6 \\
\hline \multirow{10}{*}{ HNL2 } & \multirow{10}{*}{$11 / 02 / 2004$} & \multirow{10}{*}{-136.9761} & \multirow{10}{*}{-9.046} & 10 & 0.15 & & \\
\hline & & & & 30 & 0.14 & & \\
\hline & & & & 50 & 0.15 & 2.26 & 0.35 \\
\hline & & & & 80 & 0.19 & 2.26 & 0.36 \\
\hline & & & & 110 & 0.17 & 0.92 & 0.43 \\
\hline & & & & 140 & 0.18 & 4.1 & 0.5 \\
\hline & & & & 190 & 0.14 & 5.77 & 0.64 \\
\hline & & & & 240 & 0.23 & 13.5 & 1.5 \\
\hline & & & & 290 & 0.18 & 16.7 & 2.43 \\
\hline & & & & 350 & 0.33 & 17.8 & 2.63 \\
\hline \multirow{8}{*}{ STA2 } & & & & 50 & 0.13 & 0.02 & 0.19 \\
\hline & & & & 80 & 0.16 & 0.02 & 0.19 \\
\hline & & & & 110 & 0.17 & 0.03 & 0.16 \\
\hline & & & & 140 & 0.19 & 0.29 & 0.21 \\
\hline & $11 / 04 / 2004$ & -132.3949 & -13.3054 & 190 & 0.13 & 1.41 & 0.43 \\
\hline & & & & 240 & 0.16 & 5.04 & 0.59 \\
\hline & & & & 290 & 0.11 & 8.38 & 0.9 \\
\hline & & & & 350 & 0.17 & 26.7 & 2.38 \\
\hline & & & & 40 & 0.20 & 0 & 0.17 \\
\hline & & & & 80 & 0.24 & 0 & 0.17 \\
\hline & & & & 120 & 0.17 & 0 & 0.17 \\
\hline & & & & 150 & 0.15 & 0.89 & 0.29 \\
\hline STA4 & $11 / 06 / 2004$ & -128.3849 & -16.871 & 200 & 0.12 & 1.55 & 0.32 \\
\hline & & & & 250 & 0.11 & 2.75 & 0.4 \\
\hline & & & & 300 & 0.09 & 6.93 & 0.84 \\
\hline & & & & 350 & 0.13 & 9.99 & 1.56 \\
\hline & & & & 50 & 0.11 & 0.01 & 0.15 \\
\hline & & & & 110 & 0.18 & 0.02 & 0.13 \\
\hline & & & & 150 & 0.13 & 0 & 0.13 \\
\hline STA6 & $11 / 08 / 2004$ & -123.4107 & -20.1288 & 225 & 0.13 & 1.45 & 0.28 \\
\hline & & & & 300 & 0.10 & 5.03 & 0.52 \\
\hline & & & & 350 & 0.16 & 9.65 & 1.08 \\
\hline & & & & 400 & 0.12 & 12.2 & 1.66 \\
\hline & & & & 50 & 0.15 & 0 & 0.13 \\
\hline & & & & 100 & 0.12 & 0 & 0.15 \\
\hline & & & & 200 & 0.12 & 0.01 & 0.15 \\
\hline STA8 & $11 / 10 / 2004$ & -118.3248 & -23.2879 & 300 & 0.11 & 4.38 & 0.48 \\
\hline & & & -25.2019 & 325 & 0.12 & 6.6 & 0.64 \\
\hline & & & & 350 & 0.12 & 8.87 & 0.88 \\
\hline & & & & 400 & 0.14 & 12.3 & 1.44 \\
\hline & & & & 30 & 0.12 & 0 & \\
\hline & & & & 50 & 0.11 & 0 & 0.11 \\
\hline & & & & 80 & 0.13 & 0 & 0.11 \\
\hline & & & & 100 & 0.12 & 0 & 0.12 \\
\hline & & & & 150 & 0.10 & 0.95 & 0.19 \\
\hline GYR2 & $11 / 13 / 2004$ & -114.0241 & -26.0195 & 200 & 0.11 & 3.4 & 0.41 \\
\hline & & & & 300 & 0.10 & 6.92 & 0.71 \\
\hline & & & & 325 & 0.11 & 8.46 & 0.85 \\
\hline & & & & 350 & 0.10 & 9.92 & 1.11 \\
\hline & & & & 400 & 0.15 & 12.0 & 1.67 \\
\hline
\end{tabular}


Table 1. Continued

\begin{tabular}{|c|c|c|c|c|c|c|c|}
\hline Station & $\mathrm{mon} / \mathrm{day} / \mathrm{yr}$ & Lon $\left({ }^{\circ} \mathrm{E}\right)$ & Lat $\left({ }^{\circ} \mathrm{S}\right)$ & Depth (m) & $\mathrm{DFe}(\mathrm{nM})$ & $\mathrm{NO}_{\mathrm{x}}(\mu \mathrm{M})$ & $\mathrm{PO}_{4}(\mu \mathrm{M})$ \\
\hline \multirow{9}{*}{ GYR3 } & \multirow{9}{*}{$11 / 14 / 2004$} & \multirow{9}{*}{-114.0159} & \multirow{9}{*}{-26.0444} & 50 & 0.11 & 0 & 0.09 \\
\hline & & & & 100 & 0.11 & 0 & 0.1 \\
\hline & & & & 150 & 0.10 & 0.01 & 0.12 \\
\hline & & & & 200 & 0.09 & 1.5 & 0.24 \\
\hline & & & & 250 & 0.09 & 4.98 & 0.43 \\
\hline & & & & 300 & 0.10 & 8.46 & 0.66 \\
\hline & & & & 350 & 0.09 & 15.2 & 0.99 \\
\hline & & & & 375 & 0.24 & 19.5 & 1.26 \\
\hline & & & & 400 & 0.13 & 22.1 & 1.54 \\
\hline \multirow{9}{*}{ STA12 } & \multirow{9}{*}{$11 / 21 / 2004$} & \multirow{9}{*}{-104.7419} & \multirow{9}{*}{-28.4308} & 50 & 0.15 & 0 & 0.11 \\
\hline & & & & 100 & 0.13 & 0 & 0.11 \\
\hline & & & & 150 & 0.12 & 0 & 0.11 \\
\hline & & & & 200 & 0.13 & 0.48 & 0.18 \\
\hline & & & & 250 & 0.11 & 5.47 & 0.46 \\
\hline & & & & 300 & 0.10 & 9.6 & 0.77 \\
\hline & & & & 350 & 0.29 & 16.9 & 1.24 \\
\hline & & & & 375 & 0.5 & 22.9 & 1.5 \\
\hline & & & & 400 & 0.24 & 27.9 & 1.7 \\
\hline \multirow{9}{*}{ STA14 } & \multirow{9}{*}{$11 / 23 / 2004$} & \multirow{9}{*}{-98.8609} & & 50 & 0.09 & 0 & 0.09 \\
\hline & & & & 100 & 0.08 & 0 & 0.09 \\
\hline & & & & 150 & 0.09 & 0.19 & 0.1 \\
\hline & & & & 200 & 0.09 & 1.03 & 0.15 \\
\hline & & & -29.9175 & 250 & 0.06 & 6.11 & 0.46 \\
\hline & & & -29.9173 & 300 & 0.07 & 9.86 & 0.81 \\
\hline & & & & 350 & 0.09 & 15.8 & 1.13 \\
\hline & & & & 375 & 0.22 & 19.7 & 1.38 \\
\hline & & & & 400 & 0.14 & 26.6 & 1.74 \\
\hline & & & & 30 & 0.10 & 0.04 & 0.17 \\
\hline & & & & 70 & 0.09 & 1.02 & 0.26 \\
\hline & & & & 100 & 0.08 & 1.26 & 0.24 \\
\hline & & & & 150 & 0.10 & 1.98 & 0.3 \\
\hline & & & & 200 & 0.10 & 5.68 & 0.5 \\
\hline EGY4 & $11 / 29 / 2004$ & -91.3954 & -31.8962 & 250 & 0.11 & 11.1 & 1.02 \\
\hline & & & & 300 & 0.17 & 18.1 & 1.42 \\
\hline & & & & 350 & 0.21 & 28.4 & 1.88 \\
\hline & & & & 375 & 0.29 & 30.9 & 2.05 \\
\hline & & & & 400 & 0.31 & 33 & 2.15 \\
\hline & & & & 100 & 0.13 & 6.46 & 0.48 \\
\hline & & & & 150 & 0.13 & 9.92 & 0.72 \\
\hline & & & & 200 & 0.14 & 12.7 & 1.06 \\
\hline & & & & 250 & 0.23 & 22.7 & 1.54 \\
\hline STA18 & $12 / 02 / 2004$ & -84.2061 & -32.6689 & 300 & 0.33 & 27.0 & 1.77 \\
\hline & & & & 350 & 0.89 & 34.4 & 2.28 \\
\hline & & & & 375 & 0.92 & 34.1 & 2.25 \\
\hline & & & & 400 & 0.93 & & \\
\hline & & & & 50 & 0.08 & 3.08 & 0.32 \\
\hline & & & & 130 & 0.10 & 14.0 & 0.93 \\
\hline & & & & 200 & 0.53 & 24.8 & 2.03 \\
\hline & & & & 250 & 1.16 & 32.3 & 2.53 \\
\hline STA20 & $12 / 04 / 2004$ & -780080 & -333694 & 300 & 1.14 & 35.4 & 2.57 \\
\hline SIALV & $12 / 04 / 2004$ & -10.0909 & -53.5094 & 325 & 1.11 & 36.7 & 2.53 \\
\hline & & & & 350 & 1.30 & 37.2 & 2.52 \\
\hline & & & & 375 & 1.33 & 37.0 & 2.4 \\
\hline & & & & 400 & 1.34 & 36.3 & 2.31 \\
\hline & & & & 10 & 0.32 & & \\
\hline & & & & 30 & 0.45 & & \\
\hline & & & & 50 & 0.26 & & \\
\hline & & & & 70 & 0.48 & & \\
\hline & & & & 100 & 0.67 & 27.7 & 2.03 \\
\hline & & & & 135 & 0.68 & 29.6 & 2.08 \\
\hline & & & & 170 & 0.99 & 32.3 & 2.43 \\
\hline STA22 & $12 / 06 / 2004$ & -73.4962 & -33.8009 & 205 & 1.23 & 35 & 2.53 \\
\hline & & & & 240 & 1.36 & 36.8 & 2.51 \\
\hline & & & & 275 & 1.44 & 39.6 & 2.63 \\
\hline & & & & 310 & 1.61 & 40 & 2.68 \\
\hline & & & & 345 & 1.7 & 40 & 2.56 \\
\hline & & & & 400 & 1.34 & 39.6 & 2.43 \\
\hline
\end{tabular}


Table 1. Continued

\begin{tabular}{cccccccc}
\hline Station & mon/day/yr & Lon $\left({ }^{\circ} \mathrm{E}\right)$ & $\mathrm{Lat}\left({ }^{\circ} \mathrm{S}\right)$ & $\mathrm{Depth}(\mathrm{m})$ & $\mathrm{DFe}(\mathrm{nM})$ & $\mathrm{NO}_{\mathrm{x}}(\mu \mathrm{M})$ & $\mathrm{PO}_{4}(\mu \mathrm{M})$ \\
\hline & & & 30 & 1.20 & 19.1 & 1.62 \\
& & & 75 & 1.35 & 26.9 & 2.43 \\
& & & 100 & 1.98 & 27.3 & 2.61 \\
\multirow{4}{*}{ UPX } & \multirow{3}{*}{$12 / 09 / 2004$} & -72.4047 & -34.5471 & 200 & 3.39 & 28.8 & 2.65 \\
& & & & 250 & 3.25 & 30 & 2.63 \\
& & & 300 & 3.18 & 31.2 & 2.61 \\
& & & 350 & 2.66 & 32.3 & 2.63 \\
& & & 400 & 2.78 & 34.9 & 2.63
\end{tabular}
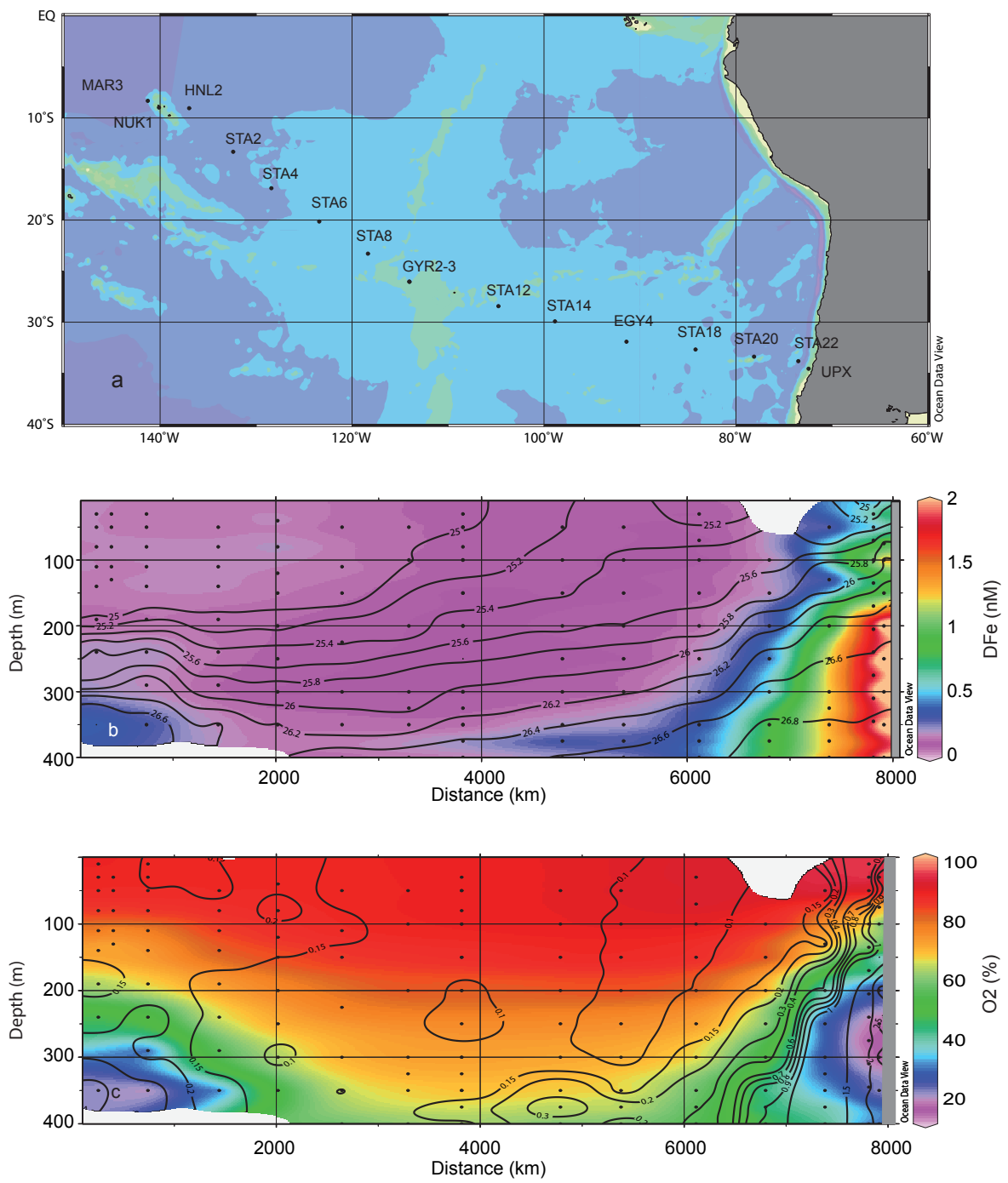

Fig. 1. Position of sampled stations during the BIOSOPE cruise (a), two dimensional distribution of DFe (b) and two dimensional distribution of the percentage of $\mathrm{O}_{2}$ saturation (c). The black lines denote the depths of the iso-density ( $\gamma$ ) (b) and the DFe concentrations (c).

\section{Results and discussion}

The two-dimensional distribution of $\mathrm{DFe}$ along the BIOSOPE transect is presented in conjunction with the iso- density lines (Fig. 1b) and overlayed on the percentage of $\mathrm{O}_{2}$ saturation (Fig. 1c). The concentrations of DFe ranged over almost two orders of magnitude from $0.061 \mathrm{nM}$ to $3.39 \mathrm{nM}$ (Table 1). In the following section we first present and 


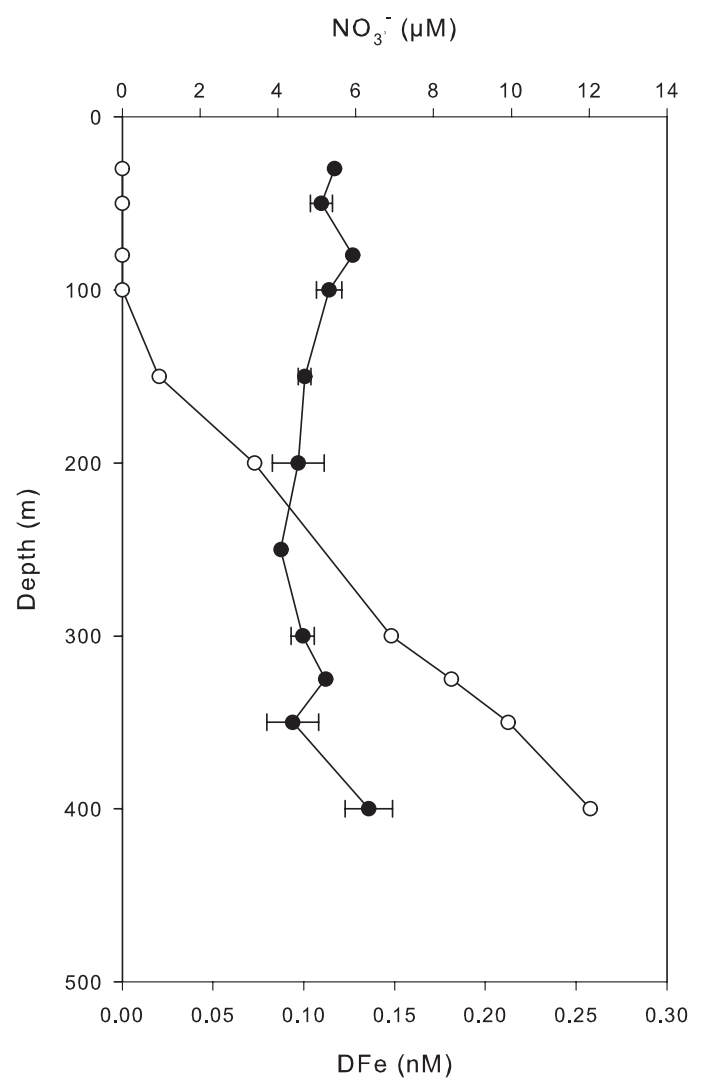

Fig. 2. Vertical distribution of DFe (black dots) and nitrate (white dots) at the station GYR. For DFe, mean values $(n=2) \pm$ one standard deviation are given.

discuss the vertical distribution of DFe in three different environments: the upwelling zone including the stations where the Oxygen Minimum Zone (OMZ) was present (stations UPX, STA18, STA20 and STA22), the HNLC region close to the Marquesas islands (stations MAR3, NUK and HNL2), and the gyre (stations STA2-14 and GYR1-2 and EGY4). When possible, the DFe distributions were compared with other sites with similar oceanographic regimes. In the second part of the paper, we consider the relationship between $\mathrm{DFe}$ and the major nutrients to discuss the status of iron as limiting factor in the different regions and the possible role of the OMZ in maintaining high DFe concentrations in the sub surface water of the low latitudes of the South Pacific.

3.1 The vertical distribution of DFe in typical oceanographic environments

\subsubsection{The coastal upwelling region}

The Chilean coastal upwelling region had the highest DFe concentrations measured during the cruise (Fig. 1, Table 1). The station UPX, located in the core of the upwelling, was characterised by high values of nitrate $(19.1 \mu \mathrm{M})$ and phos- phate $(1.2 \mu \mathrm{M})$ at $30 \mathrm{~m}$. The concentration of DFe at this depth was also high $(1.2 \mathrm{nM})$ and increased up to $3.39 \mathrm{nM}$ at $200 \mathrm{~m}$. In surface waters, DFe decreased rapidly with distance from shore and DFe concentrations at STA20 were $<0.1 \mathrm{nM}$, typical for oceanic surface waters with low iron supply. Below the mixed layer, the decrease in DFe from inshore to offshore stations was also marked. At $250 \mathrm{~m}$, DFe at STA18 was 10 fold lower than at station UPX. However, if compared to surface water, the decrease was not as abrupt and, below $200 \mathrm{~m}$, concentrations $>1 \mathrm{nM}$ were still measured at STA20 and STA22. High DFe concentrations are also reported for the Peru upwelling (from $2^{\circ} \mathrm{S}$ to $18^{\circ} \mathrm{S}$ ), (Bruland et al., 2005), but large variability was observed near the bottom depending on the size of the shelf. Concentrations of $\mathrm{DFe}$ as high as $50 \mathrm{nM}$ were associated with the widest shelf in the north, but in the southern part, where the shelf was narrow, the concentrations in near bottom suboxic waters were an order of magnitude lower (1.4-4.3 nM). We did not measure the concentrations of DFe above the Chilean shelf, but at station UPX at $100 \mathrm{~m}$, which is roughly the depth of the continental shelf in this region, DFe was $2 \mathrm{nM}$. This is in the same range as in the southern part of the Peru upwelling and could also be explained by the quite narrow shelf off Chile.

In the upwelling zone, the highest concentrations of DFe were measured between 200 and $400 \mathrm{~m}$, close to the shelf break. This part of the water column is suboxic (Fig. 1c) and associated with the relatively salty water mass of the Equatorial Sub-Surface Water (ESSW) (Blanco et al., 2001). In fact, this under-counter current is flowing poleward along the entire South American continent starting at around $5^{\circ} \mathrm{S}$ (Brink et al., 1983). When the current flows over a wide shelf it is in contact with the organic-rich shelf sediments and DFe concentrations are high. By contrast, when the current flows over a narrow shelf or along the steep continental slope, the concentrations are an order of magnitude lower but still high compared to open ocean concentrations. The suboxic conditions that prevailed are favourable conditions to maintain iron in solution in the reduced form Fe(II) which is more soluble than Fe(III). High concentration of Fe(II) have been reported (Hong and Kester 1986) off the Peru coast in samples close to the bottom, but also at stations located offshore at depth coinciding with the upper portion of the oxygen minimum.

\subsubsection{The oligotrophic gyre}

The DFe concentrations at the station GYR $\left(26^{\circ} \mathrm{S}, 114^{\circ} \mathrm{W}\right)$ are low and homogenous $(0.104 \pm 0.012 \mathrm{nM}, n=15,2$ profiles) between the surface and $350 \mathrm{~m}$ (Fig. 2). DFe vertical profiles are reported at stations located in the other subtropical gyres in the Atlantic and the Pacific (Fig. 3). In the North Pacific gyre, at station ALOHA $\left(22^{\circ} 45 \mathrm{~N}, 158^{\circ} 00 \mathrm{~W}\right)$, the near surface DFe concentrations are in the range 0.2$0.7 \mathrm{nM}$ (Boyle et al., 2005). In the western part of the subtropical North Atlantic gyre, at a station $\left(31^{\circ} 25 \mathrm{~N}, 63^{\circ} 25 \mathrm{~W}\right)$ near BATS (Bermuda Atlantic Time-Series Station), large 


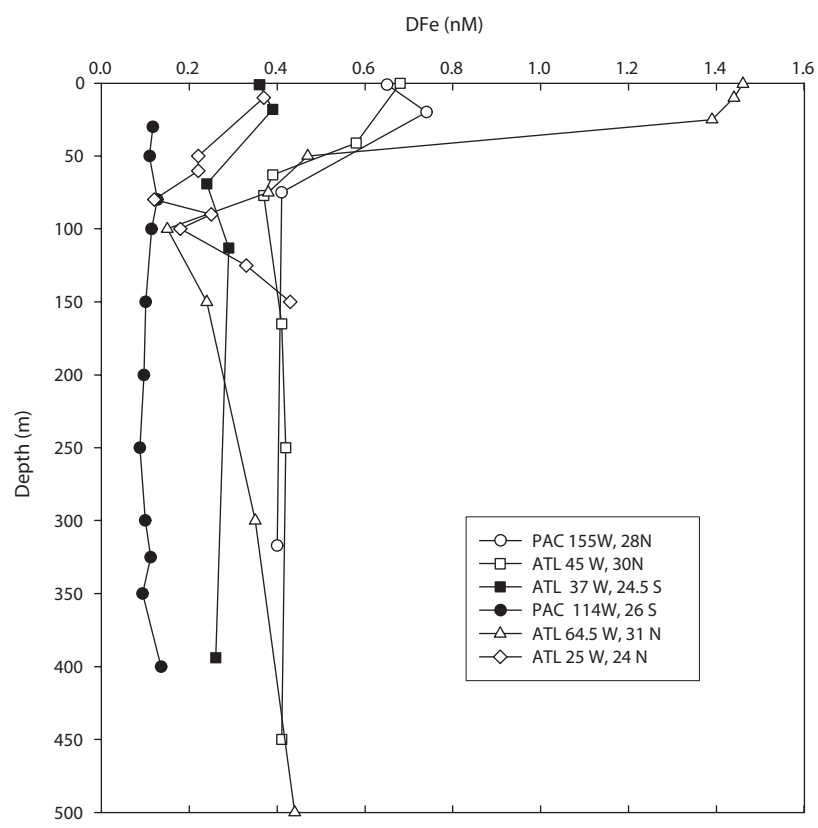

Fig. 3. Vertical profiles of DFe at different tropical and subtropical stations. Black symbols are for stations located in the Southern Hemisphere and open symbols for stations located in the Northern Hemisphere.

seasonal variations were observed ranging from $1-2 \mathrm{nM}$ to $0.1-0.2 \mathrm{nM}$ (Sedwick et al., 2005). In the centre of this gyre $\left(30^{\circ} 00 \mathrm{~N}, 45^{\circ} 00 \mathrm{~W}\right)$, DFe varied between $0.37-0.68 \mathrm{nM}$ (Bergquist and Boyle, 2006), and in eastern part of the gyre, in an area extending from the Canary Islands to the Cap Verde Islands, DFe surface concentrations were in the range 0.2-1.2 nM (Sarthou et al., 2003). In all these studies, the $\mathrm{DFe}$ variations in surface waters were attributed to the variability in dust deposition. Only few data are available for the South Atlantic gyre. At $25^{\circ} \mathrm{S}, 37^{\circ} \mathrm{W}$, a mean DFe concentration of $0.37 \pm 0.03 \mathrm{nM}$ was reported in the depth stratum 0-52 m (Bergquist and Boyle, 2006). In the Guinea gyre, DFe in surface water was significantly lower $(0.12 \pm 0.08 \mathrm{nM})$ (Sarthou et al., 2003).

The current study reveals that the concentrations in the south east Pacific subtropical gyre are among the lowest reported so far. This is consistent with the very low atmospheric iron deposition of $0.11 \pm 0.05 \mathrm{nmol} \mathrm{m}^{-2} \mathrm{~d}^{-1}$ measured during the cruise (Wagener et al., 2008). The atmospheric data revealed a very low seasonality over the BIOSOPE area, with a small maximum during spring (Wagener et al., 2008). The values of dust deposition were 12-to 3000-times lower than the dust deposition reported at BATS and ALOHA (Measures et al., 2005; Sedwick et al., 2005) and 7- to 7000-times lower than the estimates in the subtropical north east Atlantic (Sarthou et al., 2003).

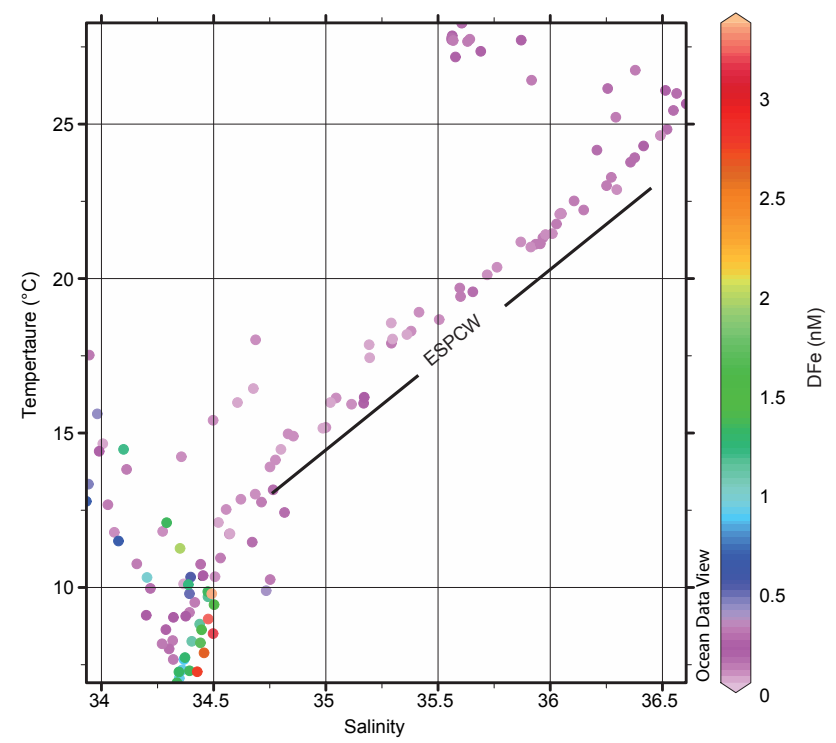

Fig. 4. Temperature versus salinity diagram with the colour of the dots scaled to DFe concentrations (see color bar). The black line denotes the occurrence of the Eastern South Pacific Central Water (ESPCW).

At the station GYR, a small increase of DFe was observed between 350 and $400 \mathrm{~m}$ (Fig. 2). This might denote the beginning of the ferricline but this cannot be confirmed due to the lack of DFe measurements at deeper depths. Even though uncertainties exist concerning the exact position of the ferricline, it is clear that it was located well below the nitracline (Fig. 2). The nutricline results from the mixing between the surface water, that is nutrient-depleted due to biological activity, and the subsurface water, that is refuelled by mineralization of sinking organic material. Lateral transport of nutrients (spreading along isopycnal surface or lateral advection) can alter the one-dimensional model. The lack of DFe vertical gradients between 0 and $350 \mathrm{~m}$ suggests that both the consumption of DFe in surface waters and the remineralisation in subsurface waters were low. This is consistent with the extremely low biomass and productivity in the hyper-oligotrophic surface waters of the gyre (Raimbault et al., 2007). The thermocline of the south east Pacific gyre is mainly ventilated by the Eastern South Pacific Central Water ESPCW characterised by a temperature-salinity relationship that spans over a large range (Fig. 4). This water mass contains low DFe concentrations $(<0.2 \mathrm{nM})$. The water mass was formed in the region between $180-150^{\circ} \mathrm{W}$ (Sprintall and Tomczak, 1992) where no measurements of DFe are available. However, low DFe concentrations are expected in this area due to the low dust deposition. The surface waters located above the ESPCW have a low productivity resulting in low particle export below the mixed layer. $\mathrm{DFe}$ produced by mineralization of sinking particles is therefore modest in the ESPCW. Consequently, the ventilation of the 

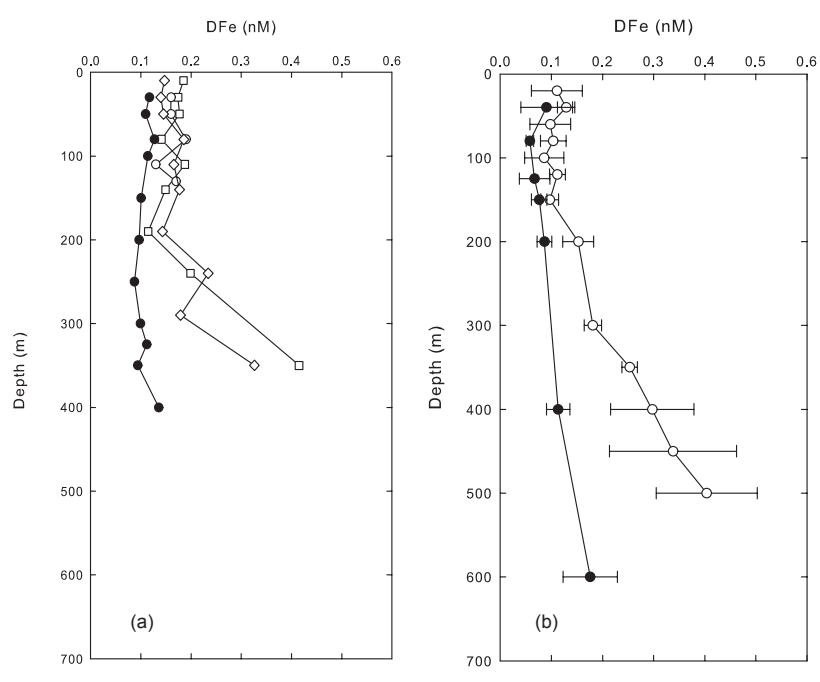

Fig. 5. Comparison of the vertical DFe distribution at stations in the vicinity of archipelagi and typical oceanic stations. (a) Vertical profiles of DFe near the Marquesas islands (open symbols) and in the centre of the South East Pacific gyre (station GYR, black symbols). (b) Vertical profiles of DFe at a station above the Kerguelen plateau (white dots) $\left(58^{\circ} 38^{\prime} \mathrm{S}, 72^{\circ} 05^{\prime} \mathrm{E}\right)$, and at an HNLC station $\left(51^{\circ} 39^{\prime}\right.$, $78^{\circ} 00 \mathrm{E}$ ) south east of the plateau (black dots) (Blain et al., 2007).

upper thermocline cannot be a large source of DFe for subsurface water in the gyre. The same conclusion was drawn by Bergquist and Boyle (2006) to explain the relatively low DFe concentrations measured in the pycnocline in the southern subtropical Atlantic gyre that is ventilated by water formed at higher latitudes were dust deposition is expected to be low.

\subsubsection{The Marquesas islands}

Vertical profiles of DFe were collected west, within and east of the Marquesas archipelago (Fig. 5a). The vertical distributions of DFe were very similar at the three stations studied. The mean concentration in the upper $80 \mathrm{~m}$ was $0.16 \mathrm{nM} \pm 0.02 \mathrm{nM}(n=11)$. This was not significantly different $(p=0.01)$ of the mean DFe $(0.13 \pm 0.03 \mathrm{nM}$ $(n=9))$ in the upper $80 \mathrm{~m}$ of the gyre (STA4-14 and GYR12). Chlorophyll- $a$ concentrations inferred from satellite images, (http://www.obs-vlfr.fr/proof/php/bio_satellite imagery.php), clearly show a strong contrast between surface waters east and west of the island. This was also confirmed by in situ measurements (Raimbault et al., 2007). It was suggested that this dissymmetry might be caused by natural iron enrichment of the HNLC water down stream the islands, similarly to the blooms in the vicinity of other islands in HNLC systems, like Galapagos (Gordon et al., 1998) or Kerguelen (Blain et al., 2007).

At a first glance it is tempting to attribute the iron source to the vicinity of the island (Signorini et al., 1999). However, the vertical profile at the shallow station (NUK) located be- tween two islands did not significantly differ from the DFe profiles at deep ocean stations located east or west of the island (Fig. 5a). There is no significant increase of DFe in surface water and this rules out the land drainage as an important source of DFe, at least at the time of the cruise. On a interannual time scale, the detailed analysis of the variation of the rainfall at the Marquesas islands do not indicate a high correlation with the Chl- $a$ inferred from satellite (Martinez and Maamaatuaiahutapu 2004). In addition to the possible input of DFe originating from the island, Signorini et al. (1999) suggested that the hydrothermal flux through old volcanic formations might also be a source of DFe. The fingerprint of hydrothermal activity in DFe vertical profiles was detectable off Hawaii (Boyle et al., 2005) at station ALOHA. At this site, the increase in dissolved and particulate $\mathrm{Fe}$ at around $1000 \mathrm{~m}$ correlated well with the highest concentration of $\delta^{3} \mathrm{He}$ (Boyle et al., 2005). Such data do not exist for the Marquesas island, but the absence of high DFe concentrations close to the island do not support the hypothesis of hydrothermal fluid injection into the water column.

A clear increase in DFe below $200 \mathrm{~m}$ was detectable at the western and eastern stations (Fig. 5a). This vertical DFe gradient was considerably steeper than at the station GYR. The origin of the enrichment in DFe near the Marquesas will be discussed in the next section, but it is interesting to compare the data in Fig. 5a with data collected in the Southern Ocean (Fig. 5b) near the Kerguelen plateau, where natural iron fertilisation of surface waters has clearly been demonstrated (Blain et al., 2007). The surface waters above and outside the plateau had similar concentrations but the gradient of DFe below $150 \mathrm{~m}$ was steeper above the Kerguelen plateau where the bloom occurred compared to outside the plateau where concentrations of Chl- $a$ were low. The deep reservoir of DFe was made available for phytoplankton by different mechanisms including diapycnal vertical mixing and deep winter mixing.

If $\mathrm{DFe}$ was responsible for the east-west difference in biomass near the Marquesas islands, mechanisms for upward transport of DFe should only exit eastward of the island. An analysis for the period 1997-2002 of sea surface height anomaly (Martinez and Maamaatuaiahutapu, 2004), Chl- $a$, wind speed and SST indicates that the bloom was strongly correlated with the total surface current (Eckman plus geostrophic), the high values of the current being associated with high values of Chl- $a$. These authors concluded that the origin of the bloom was the result of the interaction between the chain of islands and the mean flow of water masses, but the underlying mechanisms such as wind driven upwelling or mixing due to friction could not be established. Recent investigations in the vicinity of Hawaii (Benitez-Nelson et al., 2007) demonstrated that wind driven mesoscale cyclonic eddies that form in the lee of islands increased nutrient supply and primary production following the doming of isopycnal surfaces. Within oceanic eddies interaction of the wind with the underlying eddy-driven flow can 
also create episodic eddy driven upwelling supplying nutrients for surface water (Mcgillicuddy et al., 2007). All these processes have the potential to generate the complex dissymmetric and mesoscale patterns of Chl- $a$ observed around the Marquesas islands but more detailed field studies are required to elucidate the correct mechanisms.

\subsection{Application of the tracer $\mathrm{Fe}^{*}$}

The remineralisation of organic matter (OM) is a major source of macro or micro-nutriments in subsurface waters. This process is associated with the consumption of oxygen and the apparent oxygen utilisation (AOU) can provide a quantitative estimate of the amount of material that has been remineralised. We have used our data with $z>80 \mathrm{~m}$ to construct the plots of $\mathrm{PO}_{4}^{3-}, \mathrm{NO}_{3}^{-}$and $\mathrm{DFe}$ versus $\mathrm{AOU}$ that are shown in Fig. 6a, b and c, respectively. The concentrations of $\mathrm{PO}_{4}^{3-}$ are well correlated with $\mathrm{AOU}\left(r^{2}=0.9317\right)$ showing that the remineralisation of POP directly translates into DIP and that $\mathrm{PO}_{4}^{3-}$ can be used as a good tracer for the remineralisation in the studied areas. The correlation is so not obvious for $\mathrm{NO}_{3}^{-}$when the entire data set is considered. This is mainly due to loss of nitrate by denitrification or anammox in the zone where the $\mathrm{O}_{2}$ concentrations are low. No clear relation can be established between DFe and AOU (Fig. 6c). This is not surprising because the whole data set included regions were the DFe distribution was obviously impacted by processes other than remineralisation (e.g. iron input from the shelf in the upwelling region). However, a more detailed examination has revealed that there was a good linear correlation between $\mathrm{DFe}$ and $\mathrm{AOU}$, or $\mathrm{PO}_{4}^{3-}$, for the stations 18 to 22 that were typical of the OMZ. The slope of the curve, representing the typical remineralisation ratio, was $r_{(\mathrm{Fe} / \mathrm{P}) \mathrm{OMZ}}=0.99 \pm 0.11 \mathrm{mmol} \mathrm{mol}^{-1}$. The intercept of the regression line was $-1.23 \pm 0.11 \mathrm{nmoll}^{-1}$, reflecting possible excess of preformed $\mathrm{PO}_{4}^{3-}$ compared to $\mathrm{DFe}$ in this water mass. To reveal the balance between physical transport and scavenging, Parekh et al. (2005) defined $\mathrm{Fe}^{*}=(\mathrm{DFe})-r_{\mathrm{Fe} / \mathrm{P}}$ $\left(\mathrm{PO}_{4}^{3-}\right)$ which subtracts the contribution of remineralisation of $\mathrm{OM}$ to $\mathrm{DFe}$. A positive $\mathrm{Fe}^{*}$ implies that there is enough iron to support the complete consumption of $\mathrm{PO}_{4}^{3-}$ when this water is brought to the surface, and a negative $\mathrm{Fe}^{*}$ implies a deficit. We have applied this definition (using the same value of $r_{\mathrm{Fe} / \mathrm{P}}=0.47 \mathrm{~mol} \mathrm{~mol}^{-1}$ used in their work) to calculate $\mathrm{Fe}^{*}$ along the transect (Fig. 7). Positive values were observed in the upwelling region. Most other stations of the transect presented $\mathrm{Fe}^{*}$ lightly negative, except in the subsurface water near the Marquesas and near $400 \mathrm{~m}$ in the gyre where $\mathrm{Fe}^{*}$ was clearly negative. $\mathrm{Fe}^{*}$ relies on the choice of $r_{\mathrm{Fe} / \mathrm{P}}$ which is not well constrained. The ratio $r_{\mathrm{Fe} / \mathrm{P}}$ very likely depends on the degree of iron limitation of phytoplankton that has synthesized the OM (Sunda 1997). In iron-limited regimes the ratio $\left(0.2-0.5 \mathrm{mmol} \mathrm{mol}^{-1}\right)$ could be lower than in non iron-limited regions $\left(0.7-1.4 \mathrm{mmol} \mathrm{mol}^{-1}\right)$. The direct measurement of the elemental composition of diatoms collected
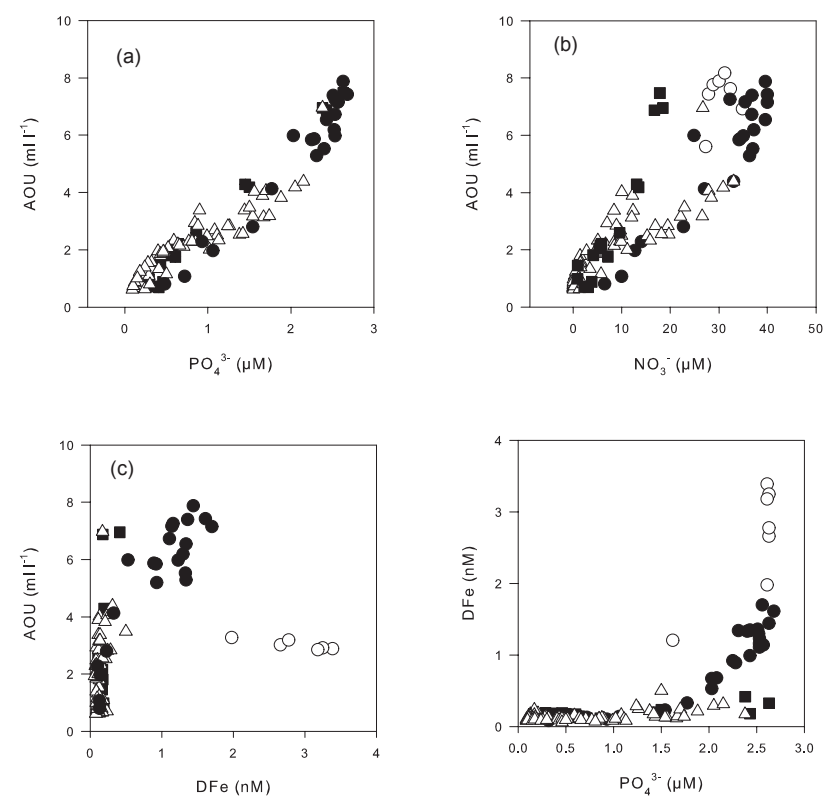

Fig. 6. Property-property diagrams for stations STA18-22 (black circles), stations UPX (white circles), stations MAR3, NUK and HNL2 (black squares), station STA2-14, GYR 2-3 and EGY (white triangles).

inside and outside the fertilised patch of SOFEX (Twining et al., 2004) confirmed this trend. For diatoms the mean Fe/P ratios were $0.71 \mathrm{mmol} \mathrm{mol}^{-1}$ and $1.9 \mathrm{mmol} \mathrm{mol}^{-1}$ in low and high $\mathrm{Fe}$ environments, respectively. In our study, $r_{\mathrm{Fe} / \mathrm{P} \text { was }}$ certainly not constant along the transect as shown by the large scatter in the data (Fig. 6d). However, the variability in the $r_{\mathrm{Fe} / \mathrm{P}}$ between 1 to $0.2 \mathrm{~mol} \mathrm{~mol}^{-1}$ does not change our conclusion that $\mathrm{Fe}^{*}<0$ and $\mathrm{Fe}^{*}>0$ occurred in subsurface waters near Marquesas and close to the Chilean coast, respectively. The qualitative examination of the distribution of DFe (Fig. 1b, c), of the vertical profiles at stations MAR3 and HNL2 (Fig. 5a), and the comparison with the distribution of DFe near Kerguelen island (Fig. 5b) suggest that there may be a source of DFe near the islands. The negative $\mathrm{Fe}^{*}$ does not confirm this idea because there was less DFe than predicted from the remineralisation of the organic matter independent of the $r_{\mathrm{Fe} / \mathrm{P}}$ values applied. The samples with negative $\mathrm{Fe}^{*}$ are located in waters with low $\mathrm{O}_{2}$ (Fig. 1c). The occurrence of the OMZ is a major feature of the water column in the South East Pacific. The biological or physical origin of the OMZ has been debated in the past (Wirtki 1962), but there is now a consensus that three major processes contribute to its formation. 1) high phytoplankton production at the surface, 2) a sharp permanent pycnocline and 3) a sluggish circulation leading to old age for subpycnocline waters. During our cruise, the OMZ was clearly identified along the Chilean coast but a global distribution of $\mathrm{O}_{2}$ in the eastern $\mathrm{Pa}-$ cific (Fig. 20 in Fiedler and Talley, 2006) shows that the subsurface waters of the stations near Marquesas are part of the 


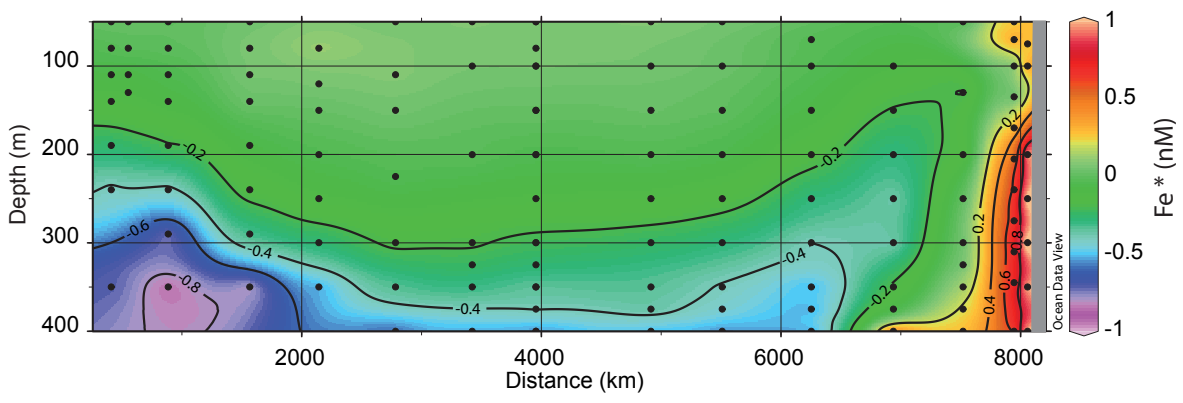

Fig. 7. Two dimensional distribution of $\mathrm{Fe} *$ calculated as $\mathrm{DFe}-r_{\mathrm{Fe} / \mathrm{P}}\left(\mathrm{PO}_{4}^{3-}\right)$ with $r_{\mathrm{Fe} / \mathrm{P}}=0.47 \mathrm{mmol} \mathrm{mol}^{-1}$.

wide OMZ extending westward from the continent. Therefore, in this region, the most appropriate ratio to be used in the calculation of $\mathrm{Fe}^{*}$ would be 1 , as determined above for the remineralisation of OM in the OMZ. This leads to largely negative values of $\mathrm{Fe}^{*}<-1 \mathrm{nM}$ in the $\mathrm{OMZ}$ near Marquesas, showing that the scavenging and slow circulation in sub pycnocline waters had dramatically reduced the concentration of $\mathrm{DFe}$ compared to $\mathrm{PO}_{4}^{3-}$. Johnson et al. (1997) have shown that the length scale for the reduction of DFe versus the distance of the source can be estimated from 1/slope of the linear plot of $\operatorname{Ln}(\mathrm{DFe})=\mathrm{f}$ (distance from the source). This corresponds to the distance at which DFe was reduced by $37 \%$ compared to the source. At $1000 \mathrm{~m}$, offshore the Californian coast, the length scale was $5000 \mathrm{~km}$. If we apply the same approach at $350 \mathrm{~m}$ using the value at stations STA20 $(1.3 \mathrm{nM})$ and MAR3 $(0.4 \mathrm{nM})$ we obtain a similar distance $(4400 \mathrm{~km})$. In both cases, the length scales were estimated at depth where the $\mathrm{O}_{2}$ concentrations were low. The reducing conditions probably contributed to maintain iron in solution.

\subsection{Potential impact of DFe distribution on biology}

The objective of the present paper was to describe and discuss the DFe distributions, but we briefly mention two potentially important implications in terms of biological activity.

i) If we assume that the relatively high biomass observed downstream the Marquesas island is due to vertical inputs of DFe from subsurface waters (see Sect. 3.1.3), the negative $\mathrm{Fe}^{*}$ values in these waters imply that the amount of DFe supplied was still in deficit compared to phosphate leading to the significant amount of unused nutrient $\left(0.3 \mu \mathrm{M}\right.$ of $\mathrm{PO}_{4}^{3-}$ and $2.2 \mu \mathrm{M}$ of $\left.\mathrm{NO}_{3}^{-}\right)$in surface waters.

ii) Our data show that $\mathrm{DFe}$ was low in the entire South Pacific gyre, but $\mathrm{NO}_{3}^{-}$was also extremely low (Raimbault et al., 2007). The limitation of primary production by $\mathrm{Fe}$ on the edges of the gyre was demonstrated by deck incubation experiments (Bonnet et al., 2007). By contrast, evidence for severe nitrogen limitation of primary production was observed in the centre of the gyre (Bon- net et al., 2007). It has been hypothesised that DFe may also regulate the rate of nitrogen fixation in such low nitrate environments. During incubation experiments carried out in the centre of the South Pacific gyre, iron addition did not stimulate nitrogen fixation (Bonnet et al., 2007; Raimbault et al., 2007). This result seems to be at odds with the possible limitation of the nitrogen fixation by iron availability. However the lack of response in this short term experiment could also be due to the quasi absence of $\mathrm{N}$-fixing populations. Temporally more detailed information is required to fully understand the role of $\mathrm{Fe}$ on primary producers in these oligotrophic waters.

Acknowledgements. We thank the captain, the officers and the crew of the R/V Atalante. We also thank P. Raimbault who performed the nutrient analysis of the Go-Flo samples, H. Claustre, leader of BIOSOPE and chief scientist of the leg1, and chief scientist A. Sciandra of the leg2. The manuscript profited from the comments of two anonymous reviewers. This is a contribution of the BIOSOPE project, funded by CNRS-INSU (LEFE CYBERprogram), CNES, ESA and NASA.

Edited by: J. Middelburg

\section{References}

Aumont, O., Maier-Reimer, E., Blain, S., and Monfray, P.: An ecosystem model of the global ocean including $\mathrm{Fe}$, $\mathrm{Si}$, P co limitations, Global Biogeochem. Cy., 17, 1060, doi:10.1029/2001GB001745, 2003.

Benitez-Nelson, C., Bidigare, R. C., Dickey, T. D., Landry, M. R., Leonard, C. L., Brown, S. L., Nencioli, F., Rii, Y. M., Maiti, K., Becker, J. W., Biddy, T. S., Black, W., Cai, W.-J., Carlson, C. A., Chen, F., Kuwahara, V. S., Lmahaffey, C., Mcandrew, P. M., Quay, P. D., Rappé, M. S., Selph, K. E., Simmonds, M. P., and Yang, E. J.: Mesoscale eddies drive increased silica export in the subtropical Pacific ocean, Science, 316, 1017-1021, 2007.

Bergquist, B. A. and Boyle, E. A.: Dissolved iron in the tropical and subtropical atlantic ocean, Global Biogeochem. Cy., 20, GB1015, doi:10.1029/2005GB002505, 2006.

Blain, S., Guieu, C., Claustre, H., Leblanc, K., Moutin, T., Quéguiner, B., and Sarthou, G.: Availability of iron and ma- 
jor nutrients for phytoplankton in the north-east Atlantic ocean, Limnol. Oceanogr., 49, 2095-2104, 2004.

Blain, S., Quéguiner, B., Armand, L., Belviso, S., Bombled, B., Bopp, L., Bowie, A., Brunet, C., Brussaard, K., Carlotti, F., Christaki, U., Corbière, A., Durand, I., Ebersbach, F., Fuda, J. L., Garcia, N., Gerringa, L. J. A., Griffiths, F. B., Guigue, C., Guillerm, C., Jacquet, S., Jeandel, C., Laan, P., Lefèvre, D., Lomonaco, C., Malits, A., Mosseri, J., Obernosterer, I., Park, Y. H., Picheral, M., Pondaven, P., Remenyi, T., Sandroni, V., Sarthou, G., Savoye, N., Scouarnec, L., Souhault, M., Thuillers, D., Timmermans, K. R., Trull, T., Uitz, J., Van-Beek, P., Veldhuis, M. J. W., Vincent, D., Viollier, E., Vong, L., and Wagener, T.: Effect of natural iron fertilisation on carbon sequestration in the Southern Ocean, Nature, 446, 1070-1075, 2007.

Blain, S., Sarthou, G., and Laan, P.: Distributions of dissolved iron during the natural iron fertilisation experiment KEOPS (Kerguelen Island, Southern Ocean), Deep Sea Res. II, doi:10.1016:j.dsr2.2007.12.008, in press, 2008.

Blanco, J. L., Thomas, A. C., Carr, M. E., and Strub, P. T.: Seasonnal climatology of hydrographic conditions in the upwelling region off nortehrn Chile, J. Geophys. Res., 106, 11 456-11467, 2001

Bonnet, S. and Guieu, C.: Atmospheric forcing on the annual iron cycle in the western Mediterranean sea, J. Geophys. Res., 111, C09010, doi:10.1029/2005JC003213, 2006.

Bonnet, S., Guieu, C., Bruyant, F., Prášil, O., Van Wambeke, F., Raimbault, P., Grob, C., Moutin, T., Gorbunov, M. Y., Zehr, J. P., Masquelier, S. M., Garczarek, L., and Claustre, H.: Nutrients limitation of primary productivity in the Southeast Pacific (BIOSOPE cruise) Biogeosciences Discuss., 4, 2733-2759, 2007 ,

http://www.biogeosciences-discuss.net/4/2733/2007/.

Boyd, P. W., Jickells, T., Law, C., Blain, S., Boyle, E. A., Buesseler, K. O., Coale, K. H., Cullen, J. J., De Baar, H. J. W., Follows, M., Harvey, M., Lancelot, C., Levasseur, M., Owens, N. J. P., Pollard, D. A., Rivkin, R. B., Sarmiento, J. L., Schoemann, V., Smetacek, V., Takeda, S., Tsuda, A., Turner, D. R., and Watson, A.: Mesoscale iron enrichment experiments 1993-2005: Synthesis and future directions, Science, 315, 612-617, 2007.

Boyle, E. A., Bergquist, B. A., Kayser, R. A., and N., M.: Iron, manganese, and lead at Hawaii Ocean Time-series station ALOHA: Temporal variability and an intermediate water hydrothermal plume, Geochimica et Cosmochimica Acta, 69, 933-952, 2005.

Brink, K. H., Halpern, D., Huyer, A., and Smith, R. L.: The physical environment of the peruvian upwelling system, Prog. Oceanogr., 12, 285-305, 1983.

Bruland, K., W., Rue, E., Smith, G. J., and Di Tullio, G. R.: Iron, macronutrient and diatom blooms in the Peru upweling regime: brown and blue waters if Peru, Mar. Chem., 93, 81-103, 2005.

Bucciarelli, E., Blain, S., and Tréguer, P.: Iron and manganese in the wake of the Kerguelen Islands (Southern Ocean), Mar. Chem., 73, 21-36, 2001.

Capone, D. G., Burns, J. A., Montoya, J. P., Michaels, A. F., Subramanian, A., and Carpenter, E. J.: New nitrogen input to the tropical North atlantic Ocean by nitrogen fixation by the cyanobacterium, trichodesnium spp., Global Biogeochem. Cy., 19, GB2024, doi:10.1029/2004GB002331, 2005.

Elrod, V. A., Berelson, W. M., Coale, K. H., and Johnson, K.: The flux of iron from continental shelf sediments: a missing source for global budgets, Geophys. Res. Lett., 31, L12307, doi:10.1029/2004GL020216, 2004.

Fiedler, P. C., and Talley, L. D.: Hydrography of the eastern tropical Paciifc: a review, Prog. Oceanogr., 69, 143-180, 2006.

Gordon, R. M., Johnson, K. S., and Coale, K. H.: The behaviour of iron and other trace elements during the ironEx-I and PlumEx experiments in the Equatorial Pacific, Deep Sea Res. II, 45, 995 1041, 1998.

Guieu, C., Bozec, Y., Blain, S., Ridame, C., Sarthou, G., and Leblond, N.: Impact of high saharan dust inputs on dissolved iron distributions in the Mediterranean sea, Geophys. Res. Lett., 29, 1911, doi:10.1029/2001GL014454, 2002.

Hong, H. and Kester, D. R.: Redox state of iron in the offshore waters of Peru, Limnol. Oceanogr., 31, 512-534, 1986.

Hutchins, D. A. and Bruland, K., W.: Iron-limited diatom growth and Si:N uptake ratios in a coastal upwelling regime, Nature, 393, 561-564, 1998.

Jickells, T. D., An, Z. S., Andersen, K. K., Baker, A. R., Bergametti, G., Brooks, N., Cao, J. J., Boyd, P. W., Duce, R. A., Hunter, K. A., Kawahata, H., Kubilay, N., Laroche, J., Liss, P. S., Mahowald, N., Prospero, J. M., Ridgwell, A. J., Tegen, I., and Torres, R.: Global Iron Connections Between Desert Dust, Ocean Biogeochemistry, and Climate, Science, 308, 67-71, 2005.

Johnson, K., Chavez, F. P., and Friederich, G. E.: Continental-shelf sediment as a primary source of iron for coastal phytoplankton, Nature, 398, 697-700, 1999.

Johnson, K. S., Gordon, R. M., and Coale, K. H.: What controls dissolved iron concentrations in the world ocean? Mar. Chem. 57, 137-161, 1997.

Karl, D. M.: Nutrient dynamics in the deep blue sea, Trends Microbiol., 10, 410-418, 2002.

Laës, A., Blain, S., Laan, P., Achterberg, E. P., Sarthou, G., and De Baar, H. J. W.: Deep dissolved iron profiles in the eastern North Atlantic in relation to water masses, Geophys. Res. Lett., 30, 1902, doi:10.1029/2003GL017902, 2003.

Laës, A., Blain, S., Laan, P., Ussher, S., Achterberg, E. P., Tréguer, P., and De Baar, H. J. W.: Sources and transport of dissolved iron and manganese along the continental margin of the Bay of Biscay, Biogeoscience, 4, 181-194, 2007.

Martin, J. H., Gordon, R. M., Fitzwater, S. E., and Broenkow, W. W.: VERTEX: phytoplankton/iron studies in the Gulf of Alaska, Deep-Sea Res. I, 36, 649-680, 1989.

Martinez, E. and Maamaatuaiahutapu, K.: Island mass effect in the Marsuesas islands: time variation, Geophys. Res. Lett., 31, L18307, doi:10.1029/2004GL020682, 2004.

Mcgillicuddy, D. J., Anderson, L. A., Bates, N. R., Biddy, T. S., Buesseler, K. O., Carlson, C. A., Davis, C. S., Ewart, C., Falkowski, P. G., Goldthwait, S. A., Hansell, D. A., Jenkins, W. J., Johnson, R., Kosnyrev, V. K., Ledwell, J. R., Li, Q. P., Siegel, D. A., and Steinberg, D. K.: Eddy/wind interactions stimulate extraordinary mid-ocean plankton blooms, Science, 316, 10211026, 2007.

Measures, C. I., Brown, M. T., and Wink, S.: Dust deposition to the surface waters of the western and central north pacific inferred from surfce water dissolved aluminum concentrations, Geochem. Geophys. Geosyst., 6, Q09M03, doi:10.1029/2005GC000922, 2005.

Mills, M. M., Ridame, C., Davey, M., La Roche, J., and Geider, J. G.: Iron and phophorus co-limit nitrogen fixation in the eastern 
tropical North ATlantic, Nature, 429, 292-294, 2004.

Moore, J. K. and Doney, S. C.: Iron availability limites the ocean nitrogen inventory stabilizing feedsback between marine denitrification and nitrogen fixation, Global Biogeochem. Cy., 21, GB2001, doi:10.1029/2006GB002762, 2007.

Moore, J. K., Doney, S. C., and Lindsay, K.: Upper ocean dynamics and iron cycling in a global three-dimensional model, Global Biogeochem. Cy., 18, GB4028, doi:10.1029/2004GB002220, 2004.

Parekh, P., Follows, M., and Boyle, E. A.: Decoupling of iron and phosphate in the global ocean, Global Biogeochem. Cy., 19, GB2020, doi:10.1029/2004GB002280, 2005.

Raimbault, P., Slawick, G., Coste, B., and Fry, J.: Feasability of using an automated colorimetric procedure for the determination of seawater nitrate in the 0 to $100 \mathrm{nM}$ range: examples from field and culture, Mar. Biol., 104, 347-351, 1900.

Raimbault, P. and Garcia, N.: Carbon and nitrogen uptake in the South Pacific Ocean: evidence for efficient dinitrogen fixation and regenerated production leading to large accumulation of dissolved organic matter in nitrogen-depleted waters, Biogeosciences Discuss., 4, 3531-3579, 2007, http://www.biogeosciences-discuss.net/4/3531/2007/.

Sarthou, G., Baker, A. R., Blain, S., Achterberg, E. P., Boye, M., Bowie, A. R., Croot, P., Laan, P., De Baar, H. J. W., Jickells, T. D., and Worsfold, P. J.: Atmospheric iron deposition and sea-surface dissolved iron concentrations in the eastern Atlantic Ocean, Deep-Sea Res. I, 50, 1339-1352, 2003.

Sedwick, P. N., Church, T. M., Bowie, A. R., Marsay, C. M., Ussher, S. J., Achilles, K. M., Lebathaby, P. J., Johnson, R. J., Sarin, M. M., and Mcgillicauddy, D. J.: Iron in the Sargasso Sea (BATS region) during summer: Eolian imprint, spatio-temporal variability, and ecological implications., Global Biogeochem. Cy., 19, GB4006, doi:10.1029/2004GB002445, 2005.
Sedwick, P. N. and Di Tullio, G. R.: Regulation of algual blooms in Antarctic shelf waters by the release of iron from melting sea ice, Geophys. Res. Lett., 24, 2515-2518, 1997.

Signorini, S. R., Mcclain, C., and Dandonneau, Y.: Mixing and phytoplankton bloom in the wake of the Marquesas Islands, Geophys. Res. Lett., 26, 3121-3124, 1999.

Sprintall, J. and Tomczak, M.: Evidence of the barrier layer in the surface layer of the tropics, J. Geophys. Res., 97, 7305-7316, 1992.

Sunda, W.: Control of dissolved iron concnetration in the world ocean: A comment, Mar. Chem., 57, 169-172, 1997.

Tréguer, P. and Le Corre, P.: Manuel d'analyse des sels nutritifs dans l'eau de mer. Utilisation de l'AutoAnalyser II Technicon, 2nd ed., Université de bretagne Occidentale, 1975.

Twining, B. S., Baines, S. B., Fisher, N. S., and Landry, M. R.: Cellular iron contents of plankton during the Southern Ocean Iron Experiment (SOFeX), Deep-Sea Res. I, 51, 1827-1850, 2004.

Wagener, T., Guieu, C., Losno, R., Bonnet, S., and Mahowald, N.: Revisiting atmospheric dust export to the southern hemisphere ocean: biogeochemical implication, Global Biogeochem. Сy., doi:10.1029/2007GB002984, in press, 2008.

Weber, L., Völker, C., Oschlies, A., and Burchard, H.: Iron profiles and speciation of the upper water column at the bermuda atlantic time-series study site: a model based sensitivity study, Biogeosciences, 4, 689-706, 2007, http://www.biogeosciences.net/4/689/2007/.

Wirtki, K.: The oxygen minima in relation to ocean circulation, Deep-Sea Res. I, 11-23, 1962. 